\title{
Deep and extensive meltwater system beneath the former Eurasian ice sheet in the Kara Sea
}

Aleksandr Montelli ${ }^{a}$, Julian A. Dowdeswella ${ }^{a}$, Anastasiya Pirogova ${ }^{b, c}$, Yana Terekhina ${ }^{b, c}$, Mikhail Tokarev ${ }^{b, c}$, Nikita Rybind, Anton Martynd, Vladislav Khoshtariya ${ }^{d}$

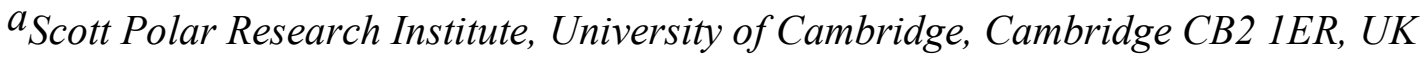

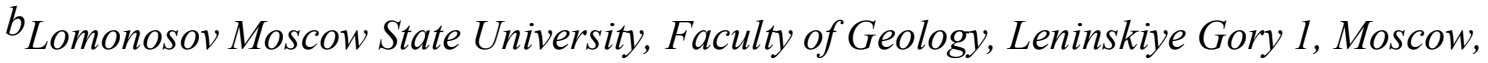
119991, Russia

${ }^{c}$ Moscow State University Seismic Data Analysis Centre, Science Park, Leninskye Gory 1 str. 77, Moscow, 119234, Russia

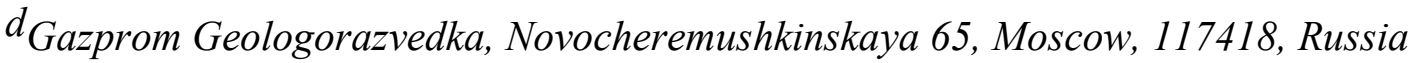

\begin{abstract}
The Eurasian ice sheet extended across the Barents and Kara seas during the late Quaternary, yet evidence on past ice dynamics and thermal structure across its huge eastern periphery remains largely unknown. Here we use three-dimensional seismic data sets covering about $4,500 \mathrm{~km}^{2}$ of the Kara Sea west of Yamal Peninsula $\left(71-73^{\circ} \mathrm{N}\right)$ to identify, for the first time in the Russian Arctic seas, several buried generations of vast subglacial tunnel valley networks. Individual valleys are up to $50 \mathrm{~km}$ long and are incised up to $400 \mathrm{~m}$ deep, being among the largest tunnel valleys ever reported. This discovery represents the first documentation of an extensively warmbased eastern margin of the Eurasian Ice Sheet during the Quaternary glaciations. The presence of major subglacial channel networks on the shallow shelf, with no evidence of ice streaming, suggests that significant meltwater discharge and subsequent freshwater forcing of ocean circulation may be long-lived rather than catastrophic, occurring during the latest stages of deglaciation in areas where the ice sheet flows slowly and is grounded largely above sea level. Furthermore, the first account of an extensive hydrological network across large areas of the Kara Sea provides important empirical evidence for active subglacial hydrological processes that should be considered in future numerical modelling of the eastern margin of the Quaternary Eurasian Ice Sheet.
\end{abstract}


Records of past ice-sheet deglaciation provide insights into ice-sheet behavior under warming climatic conditions and constrain numerical models that aim to predict future ice-sheet changes. During the Quaternary glaciations, the huge Eurasian Ice Sheet repeatedly covered large areas from southern Britain to northern Siberia, but its history in the Russian High Arctic, and in particular at its eastern periphery in the Kara Sea, remains largely unknown (e.g., Polyak et al., 2002; Svendsen et al., 2004; Hughes et al., 2016; Patton et al., 2017). This precludes accurate numerical-modelling representation of key ice-sheet characteristics, including its past extent, icedynamic configuration, and basal hydrological regime.

Of these aspects, subglacial drainage is important because the distribution and movement of meltwater beneath ice sheets plays a fundamental role in controlling ice-flow dynamics (e.g., Bartholomaus et al., 2008; Shackleton et al., 2018). Furthermore, melting ice-sheets are known to affect global sea-level and climate systems through significant freshwater discharges (Weaver et al., 2003). In the North and Barents seas, extensive channelized meltwater systems beneath the former Eurasian Ice Sheet have been inferred from multiple generations of irregular subglacial channels, commonly referred to as tunnel valleys (e.g., Stewart and Lonergan, 2011; van der Vegt et al., 2012; Bjarnadóttir et al., 2017). In the Russian High Arctic, however, there remains a critical knowledge gap on subglacial drainage, although recent numerical models suggest that during the Last Glacial Maximum the Eurasian Ice Sheet remained permanently cold-based and meltwater-free at its eastern margin (Patton et al., 2017; Shackleton et al., 2018). In our study, high-resolution three-dimensional (3D) seismic data from the southern Kara Sea document, for the first time, multiple generations of deep and extensive subglacial tunnel valleys (e.g., Ó Cofaigh, 1996). Here, we discuss our findings on tunnel valley configuration, genesis and relation to ice-sheet flow regime, and place these results into the context of modern ice-sheet dynamics and their relevance for calibration of existing numerical models.

\section{DATA AND METHODS}

Two 3D seismic data sets covering $4,500 \mathrm{~km}^{2}$ of the shallow shelf west of Yamal Peninsula, Siberia (Fig. 1A) were acquired in 2016 (commissioned by Gazprom Geologorazvedka, Moscow) using eight 5-km-long streamers towed at $8 \mathrm{~m}$ water depth. The seismic source was an array of bolt airguns with a total volume of 3,630 in ${ }^{3}$ and a signal frequency range from 2 to 200 Hz. The processed 3D seismic data were time-migrated stacks with a $2 \mathrm{~ms}$ sampling rate and a bin size of 12.5 by $25 \mathrm{~m}$. Processing flow included amplitude correction, bandpass filtering, debubbling, multiple removal, deconvolution, and velocity analysis with 1 by $1 \mathrm{~km}$ steps. Attribute analysis involved calculation of coherency variance within the time-migrated 3D 
cubes. 3D data were complemented by regional seismic lines (Fig. 1E) acquired by the Marine Arctic Geological Expedition (Portnov et al., 2018). Mean sound velocity of $2000 \mathrm{~m} / \mathrm{s}$ was used for time-depth conversions in the upper sedimentary succession. In addition, drilling samples from four boreholes (Fig. 1A) collected in 1991 by Arktikmorneftegazrazvedka at 70 to $130 \mathrm{~m}$ water depths within $50 \mathrm{~km}$ of the 3D surveys were used to estimate the approximate thickness of Quaternary sediments in the study area.

\section{BURIED CHANNELS}

\section{Description}

Seismic data reveal an extensive network of buried sinuous and straight incisions. Complex cross-cutting relationships indicate multiple generations of these features (Fig. 2). Following extensive mapping of over 70 incisions across the two 3D seismic cubes (Fig. 1B), these erosional features were classified based on their configuration and morphology into two distinct types: (1) large, irregular elongate depressions and (2) narrow, shallow meandering channels.

Incisions of the first type comprise large curvilinear and straight depressions with variable width of $1-6 \mathrm{~km}$. In some cases, they bifurcate and rejoin, forming an integrated network. They are up to $50 \mathrm{~km}$ long and are incised up to $\sim 400 \mathrm{~m}$ deep into the underlying substrate, with their tops being buried no deeper than $100 \mathrm{~m}$ below the seafloor (Fig. 2A, B). Four drill cores collected near the 3D seismic survey areas (Fig. 1B) show that the thickness of Quaternary sediments in the study area ranges from 126 to $151 \mathrm{~m}$, implying a Quaternary age for the type 1 erosional depressions, with some of these deep features being carved not only into the Quaternary deposits, but also into the underlying Tertiary and Cretaceous sedimentary rocks. Type 1 features are characterized by abrupt terminations and irregular configuration with respect to each other (Fig. 2). Many of these incisions have strongly undulating longitudinal profiles, with highamplitude fluctuations of up to $200 \mathrm{~m}$ along their thalwegs (Fig. 3).

Incisions of the second type are much narrower, with smooth thalwegs and relatively uniform width along their length. They are up to $450 \mathrm{~m}$ wide, $20 \mathrm{~km}$ long and incised up to $30 \mathrm{~m}$ deep. These features demonstrate distinctive meandering patterns and, in some cases, show evidence of coalescence with smaller tributaries (Fig. 2E, F). The most deeply buried meandering channel was found on the $1500 \mathrm{~ms}$ time slice of the survey 1 (Fig. 1B), >1 km below the base of the Quaternary succession, while the youngest channel, found in the survey 2 area to the south, is carved into the uppermost erosional surface close to the seafloor (Fig. 2F). 


\section{Interpretation}

The highly irregular, overdeepened bottom profiles of the type 1 incisions (Fig. 3) indicate that erosion must have occurred under significant hydrostatic pressure gradients, with water being driven against the local slopes (Ó Cofaigh, 1996; Lonergan et al., 2006). Furthermore, the incision depths of up to $400 \mathrm{~m}$ by far exceed Quaternary glacioeustatic sea-level fluctuations of $\sim 130 \mathrm{~m}$, making explanation of their genesis by river erosion even more problematic (Huuse and Lykke-Andersen, 2000). Therefore, the large overdeepened depressions are interpreted as tunnel valleys - large meltwater channels formed subglacially, close to the retreating margins of melting ice-sheets (e.g., Ó Cofaigh, 1996; Lonergan et al., 2006; Stewart and Lonergan, 2011; Kehew et al., 2012).

In contrast to the type 1 tunnel valleys, the dimensions, sinuosity and distinctive meandering configuration of type 2 incisions suggest their interpretation as buried river valleys. Their presence both above the youngest type 1 tunnel valleys, as well as within the Cretaceous section $>1 \mathrm{~km}$ below the glacigenic sedimentary succession corroborates a fluvial interpretation of their origin.

\section{DISCUSSION}

\section{Paleoenvironmental Evolution in the Southern Kara Sea}

The discovery of tunnel valleys in the Kara Sea is of significance as it implies abundant meltwater production underneath an extensive area of the Eurasian Ice Sheet's eastern periphery at a number of stratigraphic intervals during the Quaternary. Although the lack of accurate dating precludes establishing the absolute ages of major meltwater drainage events, analysis of chronologically constrained seismic data in the North Sea attributed separate generations of similar tunnel valleys to individual glacial-interglacial cycles (Stewart and Lonergan, 2011). Thus, the meltwater features reported here are likely to have formed over multiple glacialinterglacial cycles of the Quaternary.

The sedimentary cover overlying the tops of the uppermost tunnel valleys thickens from 10 to 50 $m$ towards the Yamal Peninsula (Fig. 1E). Therefore, unless Holocene sedimentation rates in the area were extremely high (i.e., over $5 \mathrm{~m} \mathrm{k.yr}^{-1}$ ), the uppermost tunnel-valley generation is likely to have been produced prior to the Late Weichselian (25-10 ka). Previous Eurasian Ice Sheet reconstructions indicate that eastern margin of the Late Weichselian ice sheet was limited to the trough immediately east of Novaya Zemlya (Fig. 1A; Svendsen et al., 2004; Batchelor et 
al., 2019), where it was permanently cold based during 25-20 ka according to numerical models (Shackleton et al., 2018). If these reconstructions are correct, then the drastic changes in icesheet extent and subglacial thermal regime imply profound climatic shifts that took place in the Arctic, tentatively during the Weichselian (100 to $20 \mathrm{ka}$ ), accompanied by substantial changes to precipitation patterns to the east of the Novaya Zemlya archipelago (Svendsen et al., 2004).

\section{Mechanisms of tunnel valley formation and their relation to ice flow}

Although tunnel valleys are known to be formed by subglacial meltwater, their exact genesis remains debated between two end-member process models: (1) catastrophic formation by outburst floods resulting from rapid drainage of meltwater reservoirs, including subglacial lakes; and (2) gradual steady-state formation by headward sapping in low-pressure subglacial channels (Ó Cofaigh, 1996; Kehew et al., 2012; Livingstone and Clark, 2016). Data presented here indicate that in some cases individual tunnel valley segments begin and terminate abruptly (e.g., Valley 3 in Fig. 3) and there is no clear evidence for their connection to subglacial lakes, which have been previously imaged seismically as distinct basins covered by an acoustically stratified sedimentary drape (e.g., Simkins et al., 2017). Here, we find no geological evidence of subglacial reservoirs that could have provided the huge amounts of meltwater required to erode valleys of such dimensions during a single outburst event. Furthermore, similarly to the huge valley systems in the North Sea, the infill stratigraphy of our Kara Sea type 1 channels shows evidence of valley reoccupation, indicating that the channels were active over long periods of time and were formed by multiple drainage events, thus favoring more gradual steady-state water flow for their formation (Lonergan et al., 2006).

Another important aspect of subglacial tunnel valleys is the ice-flow conditions under which they form. Meltwater channels found previously in the Northern Hemisphere (Stewart and Lonergan, 2011; Livingstone and Clark, 2016; Montelli et al., 2017; Bjarnadóttir et al., 2017) indicate that they typically occupy flat terrestrial and shallow marine beds, and are rarely associated with fast-flowing ice streams, which tend to erode overdeepened cross-shelf troughs on continental shelves (Batchelor and Dowdeswell, 2014). In Antarctica, geophysical studies of former ice-stream locations have shown only fragmentary evidence of deep meltwater channels, predominately incised into bedrock on the inner continental shelves (Ó Cofaigh et al., 2002; Nitsche et al., 2013; Kirkham et al., 2019), as well as small-scale sedimentary channel networks formed by outburst drainage from upstream subglacial lakes (Simkins et al., 2017). Deep valleys found in early glacial sedimentary record in East Antarctica were probably formed prior to the development of major ice streams (Montelli et al., 2019). In our study area, as in the shallow 
North Sea, seismic slices reveal no evidence of buried troughs and/or elongate, streamlined landforms that could conclusively diagnose the presence of ice streams, highlighting that slowflowing, inter-ice stream ice-sheet sectors may provide a more favorable setting for the development of deep tunnel valley networks compared to the dynamic, fast-flowing ice streams (Lonergan et al., 2006; Dowdeswell et al., 2007).

\section{Deglacial timing of tunnel valley formation}

Models of the Eurasian Ice Sheet and sea-level fluctuations indicate that vast parts of the relatively shallow eastern side of the Kara Sea were repeatedly exposed sub-aerially during late Quaternary glacial periods (Svendsen et al., 2004; Patton et al., 2016). In the study area, this observation is supported by at least the youngest tunnel valleys being incised by rivers immediately above (Fig. 2A). This stratigraphic relationship implies that, following regional deglaciation, the shallow shelf off the Yamal Peninsula remained sub-aerially exposed, allowing the formation of rivers until the region finally submerged under rising deglacial sea levels. Thus, it is suggested here that an extensive subglacial hydrological system in the Kara Sea was active during the final deglaciation stages, forming under the shrinking, slow-flowing ice cover that was grounded largely above sea-level.

Analysis of the Northern Hemisphere distribution of tunnel valleys by Livingstone and Clark (2016) showed that they tend to occur near the southernmost ice-sheet limits, implying their formation during initial deglaciation stages. However, smaller examples of tunnel valleys mapped recently in the deeper parts (e.g., 200-300 m) of the modern Barents Sea showed that meltwater channel systems can also form at higher latitudes in interior ice-sheet sectors during late deglaciation (Bjarnadóttir et al., 2017). The data presented here corroborate this evidence, but in contrast with the Barents Sea, tunnel valleys buried in the Kara Sea are among the deepest meltwater features ever reported, comparable only to analogues from the much more southerly shallow North Sea shelf, which was above sea-level during initial deglaciation stages (Huuse and Lykke-Andersen, 2000; Patton et al., 2016). Thus, in both the North and Kara seas, a slowflowing ice-sheet grounded largely above sea level would be less sensitive to ocean warming and would provide a relatively stable glaciological setting, allowing enough time for subglacial conduits to develop into an extensive channelized hydrological system as more water was discharged through them.

Based on our observations of widespread tunnel valleys across the southern sector of the Kara Sea, it is further hypothesized that the vast subglacial meltwater channel system may well have 
extended latitudinally across much of the shallow Kara Sea shelf as far as the Severnaya Zemlya archipelago at $80^{\circ} \mathrm{N}$ (Fig. 1), during the most extensive glaciations of the Quaternary. The discovery of an extensive subglacial channel network across large areas of the Kara Sea, unexpected in existing numerical simulations (Patton et al., 2017; Shackleton et al., 2018), provides robust empirical evidence for subglacial hydrological processes that should be incorporated into the numerical models that simulate ice-sheet responses to warming environmental conditions.

\section{ACKNOWLEDGEMENTS}

We thank Gazprom Geologorazvedka for permission to reproduce seismic data sets for this work. Authors acknowledge MAGE (Marine Arctic Geological Expedition), FGBU VNIIOKEANGEOLOGIYA and Alexey Portnov for providing 2D seismic data. Thank you to Frank Nitsche, Lilja Bjarnadóttir and anonymous reviewer for commenting on the manuscript, and to Phil Gibbard for useful discussions prior to the publication.

\section{REFERENCES}

Bartholomaus, T.C., Anderson, R.S., and Anderson, S.P., 2008, Response of glacier basal motion to transient water storage: Nature Geoscience, v. 1, no. 1, p. 33-37.

Batchelor, C.L., and Dowdeswell, J., 2014, The physiography of High Arctic cross-shelf troughs: Quaternary Science Reviews, v. 92, p. 68-96.

Batchelor, C.L., Margold, M., Krapp, M., Murton, D.K., Dalton, A.S., Gibbard, P.L., Stokes, C.R., Murton, J.B. and Manica, A., 2019, The configuration of Northern Hemisphere ice sheets through the Quaternary: Nature Communications, v. 10, 3713, no. 1, p. 1-10.

Bjarnadóttir, L.R., Winsborrow, M., and Andreassen, K., 2017, Large subglacial meltwater features in the central barents sea: Geology, v. 45, no. 2, p. 159-162.

Dowdeswell, J.A., Ottesen, D., Rise, L., and Craig, J., 2007, Identification and preservation of landforms diagnostic of past ice-sheet activity on continental shelves from three-dimensional seismic evidence: Geology, v. 35, no. 4, p. 359-362.

Hughes, A.L.C., Gyllencreutz, R., Lohne, O.S., Mangerud, J. and Svendsen, J.I., 2016. The last Eurasian ice sheets - a chronological database and time-slice reconstruction, DATED-1: Boreas, v. 45 , p. 1-45. 
Huuse, M., and Lykke-Andersen, H., 2000, Overdeepened Quaternary valleys in the eastern Danish North Sea: morphology and origin: Quaternary Science Reviews, v. 19, no. 12, p. $1233-$ 1253.

Kehew, A.E., Piotrowski, J.A., and Jørgensen, F., 2012, Tunnel valleys: Concepts and controversies - A review: Earth-Science Reviews, v. 113, no. 1-2, p. 33-58, doi:10.1016/j.earscirev.2012.02.002.

Kirkham, J.D., Hogan, K.A., Larter, R.D., Arnold, N.S., Nitsche, F., Golledge, N.R. and Dowdeswell, J.A., 2019, Past water flow beneath Pine Island and Thwaites glaciers, West: The Cryosphere, v. 13, p. 1959-1981.

Livingstone, S.J., and Clark, C.D., 2016, Morphological properties of tunnel valleys of the southern sector of the Laurentide Ice Sheet and implications for their formation: Earth Surface Dynamics, v. 4, p. 567-589.

Lonergan, L., Maidment, S.C., and Collier, J.S., 2006, Pleistocene subglacial tunnel valleys in the central North Sea basin: 3-D morphology and evolution: Journal of Quaternary Science: Published for the Quaternary Research Association, v. 21, no. 8, p. 891-903.

Montelli, A., Dowdeswell, J.A., Ottesen, D., and Johansen, S., 2017, Ice-sheet dynamics through the Quaternary on the mid-Norwegian continental margin inferred from 3D seismic data: Marine and petroleum geology, v. 80, p. 228-242.

Montelli, A., Gulick, S.P., Fernandez, R., Frederick, B.C., Shevenell, A.E., Leventer, A. and Blankenship, D.D., 2019, Seismic stratigraphy of the Sabrina Coast shelf, East Antarctica: Early history of dynamic meltwater-rich glaciations: Geological Society of America Bulletin.

Nitsche, F.O., Gohl, K., Larter, R.D., Hillenbrand, C.D., Kuhn, G., Smith, J., Jacobs, S.S., Anderson, J., and Jakobsson, M., 2013, Paleo ice flow and subglacial meltwater dynamics in Pine Island Bay, West Antarctica: The Cryosphere, v. 7, p. 249-262.

Ó Cofaigh, C., 1996, Tunnel valley genesis: Progress in physical geography, v. 20, no. 1, p. 119.

Ó Cofaigh, C., Pudsey, C.J., Dowdeswell, J.A., and Morris, P., 2002, Evolution of subglacial bedforms along a paleo-ice stream, Antarctic Peninsula continental shelf: Geophysical Research Letters, v. 29, no. 8, p. 41-45.

Patton, H., Hubbard, A., Andreassen, K., Auriac, A., Whitehouse, P.L., Stroeven, A.P., Shackleton, C., Winsborrow, M., Heyman, J., and Hall, A.M., 2017, Deglaciation of the Eurasian ice sheet complex: Quaternary Science Reviews, v. 169, p. 148-172.

Patton, H., Hubbard, A., Andreassen, K., Winsborrow, M., and Stroeven, A.P., 2016, The buildup, configuration, and dynamical sensitivity of the Eurasian ice-sheet complex to Late Weichselian climatic and oceanic forcing: Quaternary Science Reviews, v. 153, p. 97-121, doi:10.1016/j.quascirev.2016.10.009. 
Polyak, L., Gataullin, V., Gainanov, V., Gladysh, V., and Goremykin, Y., 2002, Kara Sea expedition yields insight into extent of LGM ice sheet: Eos (Transactions American Geophysical Union), v. 83, no. 46, p. 525-529.

Portnov, A., Mienert, J., Winsborrow, M., Andreassen, K., Vadakkepuliyambatta, S., Semenov, P., and Gataullin, V., 2018, Shallow carbon storage in ancient buried thermokarst in the South Kara Sea: Scientific reports, v. 8, 14342, no. 1, p. 1-8.

Shackleton, C., Patton, H., Hubbard, A., Winsborrow, M., Kingslake, J., Esteves, M., Andreassen, K., and Greenwood, S.L., 2018, Subglacial water storage and drainage beneath the fennoscandian and barents sea ice sheets: Quaternary Science Reviews, v. 201, p. 13-28.

Simkins, L.M., Anderson, J.B., Greenwood, S.L., Gonnermann, H.M., Prothro, L.O., Halberstadt, A.R.W., Stearns, L.A., Pollard, D., and DeConto, R.M., 2017, Anatomy of a meltwater drainage system beneath the ancestral East Antarctic ice sheet: Nature Geoscience, v. 10, no. 9, p. 691-698.

Stewart, M.A., and Lonergan, L., 2011, Seven glacial cycles in the middle-late Pleistocene of northwest Europe: Geomorphic evidence from buried tunnel valleys: Geology, v. 39, no. 3, p. 283-286, doi:10.1130/G31631.1.

Svendsen, J.I., Alexanderson, H., Astakhov, V.I., Demidov, I., Dowdeswell, J.A., Funder, S., Gataullin, V., Henriksen, M., Hjort, C., Houmark-Nielsen, M., Hubberten, H.W., Ingólfsson, Ó., Jakobsson, M., Kjær, K.H., Larsen, E., Lokrantz, H., Lunkka, J.P., Lyså, A., Mangerud, J., Matiouchkov, A., Murray, A., Möller, P., Niessen, F., Nikolskaya, O., Polyak, L., Saarnisto, M., Siegert, C., Siegert, M.J., Spielhagen, R.F., and Stein, R., 2004, Late Quaternary ice sheet history of northern Eurasia: Quaternary Science Reviews, v. 23, no. 11-13, p. 1229-1271, doi:10.1016/j.quascirev.2003.12.008.

van der Vegt, P., Janszen, A., and Moscariello, A., 2012, Tunnel valleys: current knowledge and future perspectives: Geological Society, London, Special Publications, v. 368, no. 1, p. 75-97.

Weaver, A.J., Saenko, O.A., Clark, P.U., and Mitrovica, J.X., 2003, Meltwater pulse 1A from Antarctica as a trigger of the Bølling-Allerød warm interval: Science, v. 299, no. 5613, p. 17091713. 


\section{FIGURE CAPTIONS}

Figure 1: Channel systems buried within the upper $\sim 400 \mathrm{~m}$ of the southeast Kara Sea continental shelf. A. Bathymetry of the Russian Barents and Kara seas (from International Bathymetric Chart of the Arctic Ocean [IBCAO], ver. 3.0, https://www.ngdc.noaa.gov/mgg/bathymetry/arctic/arctic.html)), showing the locations of blocks of three-dimensional (3D) seismic site survey data (in red), two-dimensional (2D) seismic profiles (black lines) and four wells in their vicinity (yellow dots). Contours on the shelf every $100 \mathrm{~m}$. Dashed line is the Eurasian Ice Sheet extent during the Last Glacial Maximum; modified from Svendsen et al. (2004). B. Zoomed-in bathymetry of the continental shelf west of Yamal Peninsula showing multiple generations of tunnel valleys mapped from 3D seismic data. Tunnel valleys are coloured according to their relative age (indicated in the legend) inferred from their cross-cutting relationships. C. Horizontal seismic section (slice) at $300 \mathrm{~ms}$ two-way traveltime (TWT) in the coherence domain through seismic survey 1 showing several generations of large buried tunnel valleys immediately west of Yamal Peninsula. D. Vertical seismic section showing the acoustic character and anatomy of valleys shown in Fig. 1C. Note that the southernmost valley is almost $400 \mathrm{~m}$ deep. E. High-resolution 2D seismic profiles showing regional lateral extent of large buried valleys in the southern Kara Sea. Depth values are in two-way traveltime (TWT).

Figure 2: Examples of buried channels mapped from 3D seismic survey 2 data in the southeastern Kara Sea (located in Fig. 1). A and B. Orthogonally intersecting vertical seismic sections from $3 \mathrm{D}$ seismic data set showing at least four generations of type 1 channels, interpreted as subglacial tunnel valleys and, both above and below them, type 2 channels, interpreted as palaeo-rivers. Note that tops of tunnel valleys are only found within upper $100 \mathrm{~m}$ of Quaternary sedimentary succession on the continental shelf. Valleys 1-3 refer to three selected type-1 channels analyzed morphometrically in Fig. 3. C and D. Horizontal sections through the same 3D seismic survey, in coherence and amplitude domains, respectively, at $325 \mathrm{~ms}$ TWT beneath the sea surface, clearly showing large and deep tunnel valleys (type 1 channels) in the study area. E. Zoomed-in sector (location shown by red dotted box in Fig. 2D) of same 3D seismic block showing horizontal section at $425 \mathrm{~ms}$ TWT with small meandering palaeo-river (type 2 channel). Note abandoned meander indicating river avulsion. F. Zoomed-in sector (location shown by green dotted box in Fig. 2D) of the same 3D seismic block showing a horizontal section at $220 \mathrm{~ms}$ with small palaeo-rivers (type 2 channels), incised into the uppermost erosional surface containing the youngest tunnel valleys (type 1 channels) and buried under only $\sim 30 \mathrm{~m}$ of sediment.

Figure 3: 3D morphology of three selected type 1 incisions, interpreted as tunnel valleys, imaged and labelled in Fig. 2D, showing their variable width and the highly undulating character of their longitudinal profiles indicative of waterflow under pressure in subglacial channels. On the inset - longitudinal profiles of respective valleys, with vertical axis corresponding to their depth values in two-way traveltime (TWT), and horizontal axis corresponding to the distance along the thalweg (in $\mathrm{km}$ ). 

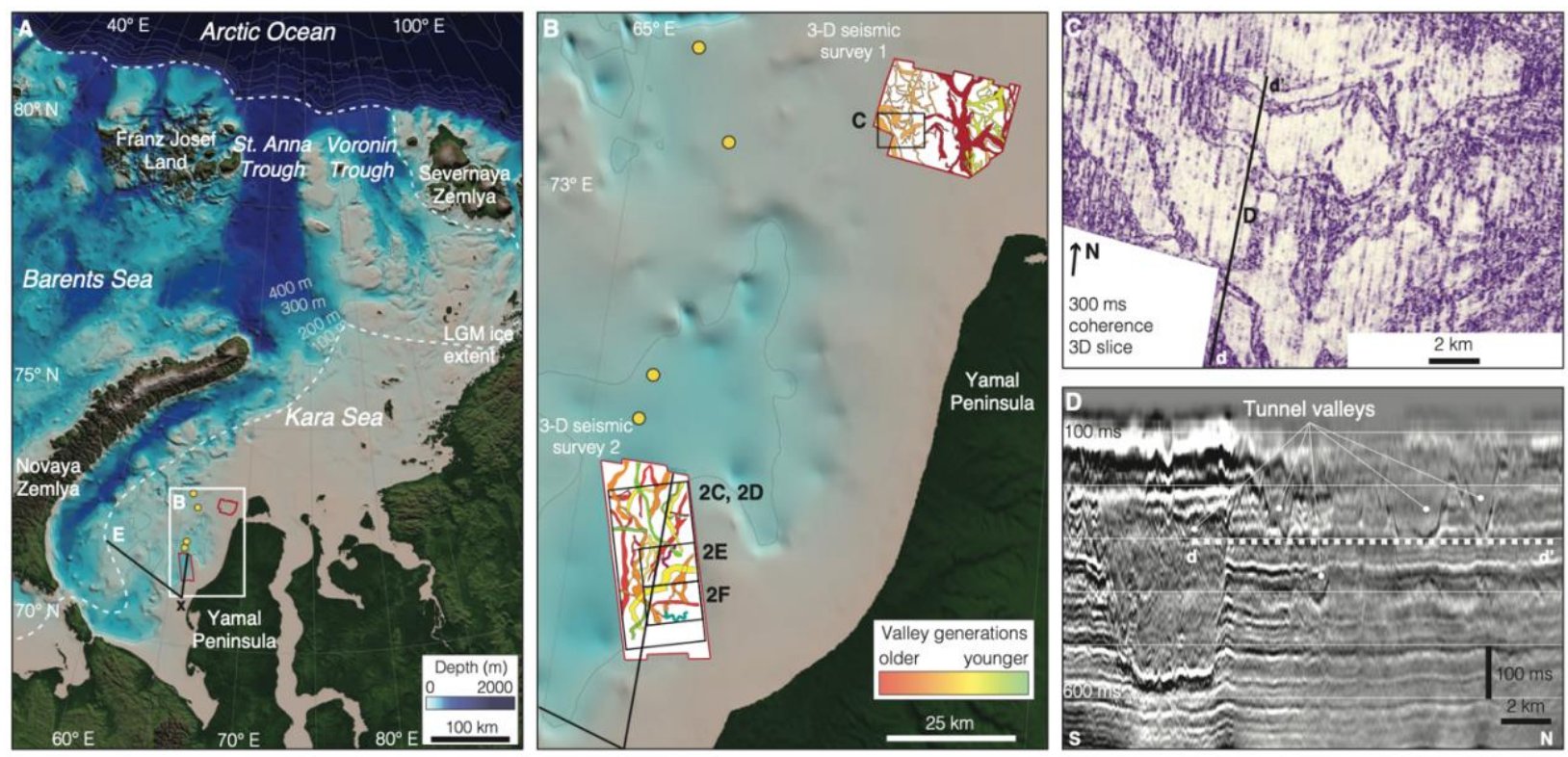

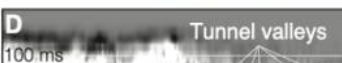

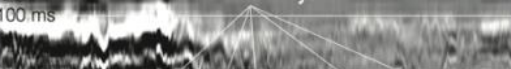
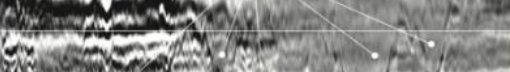

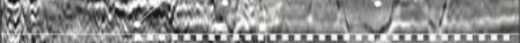

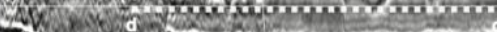

s.

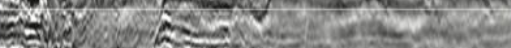

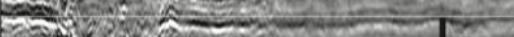

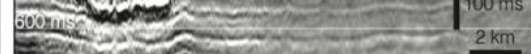

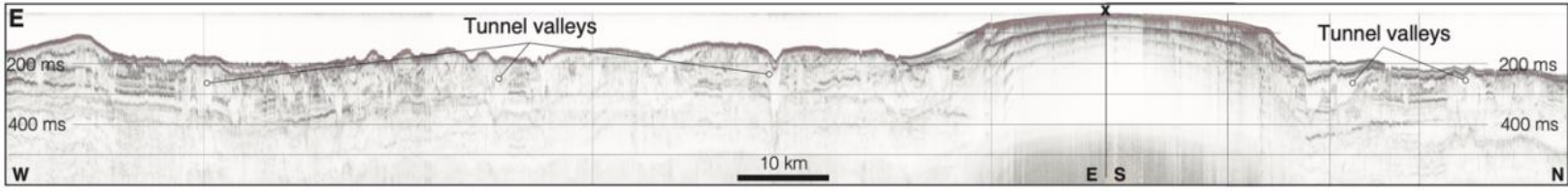

Figure 1 

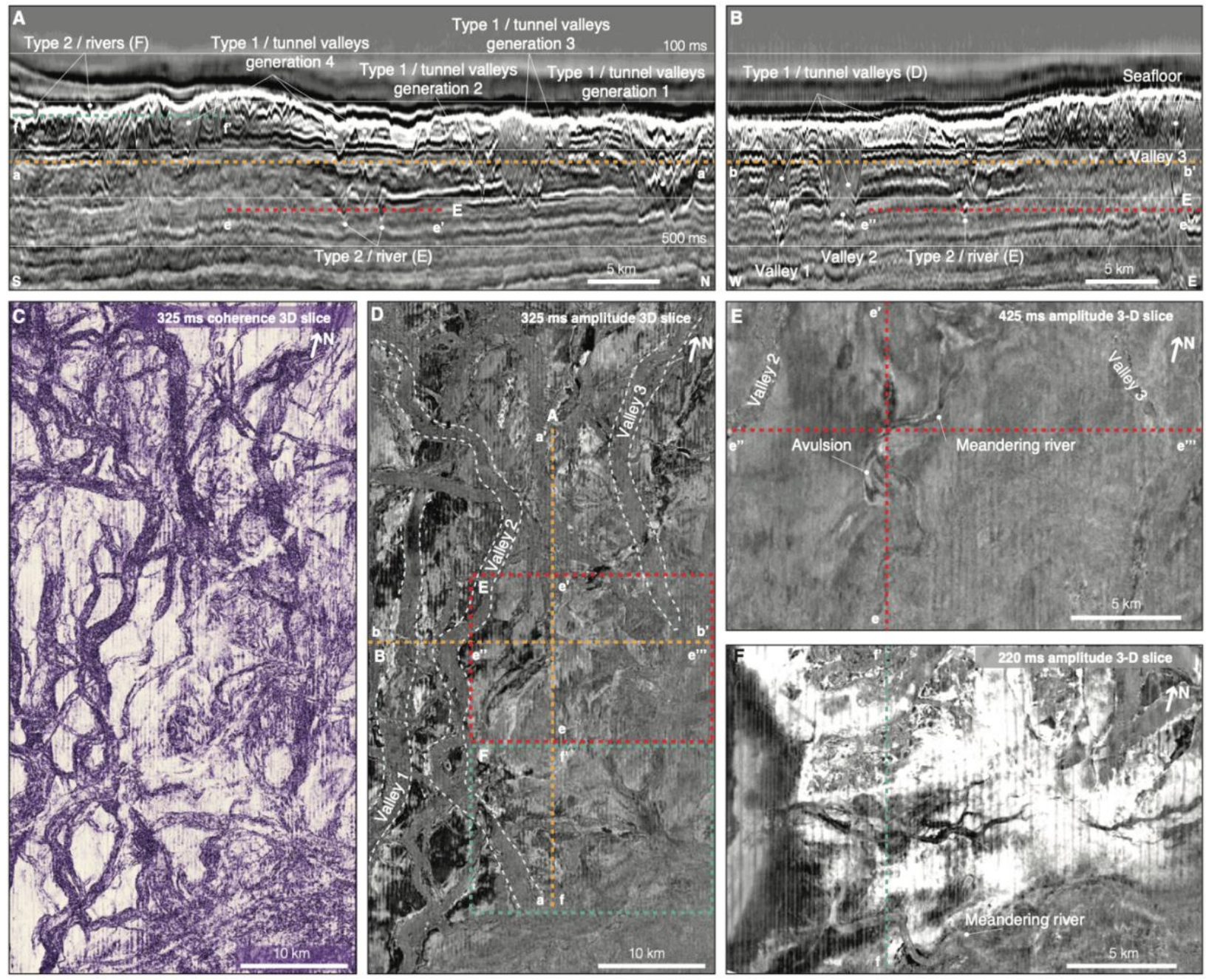

Figure 2

Figure 3

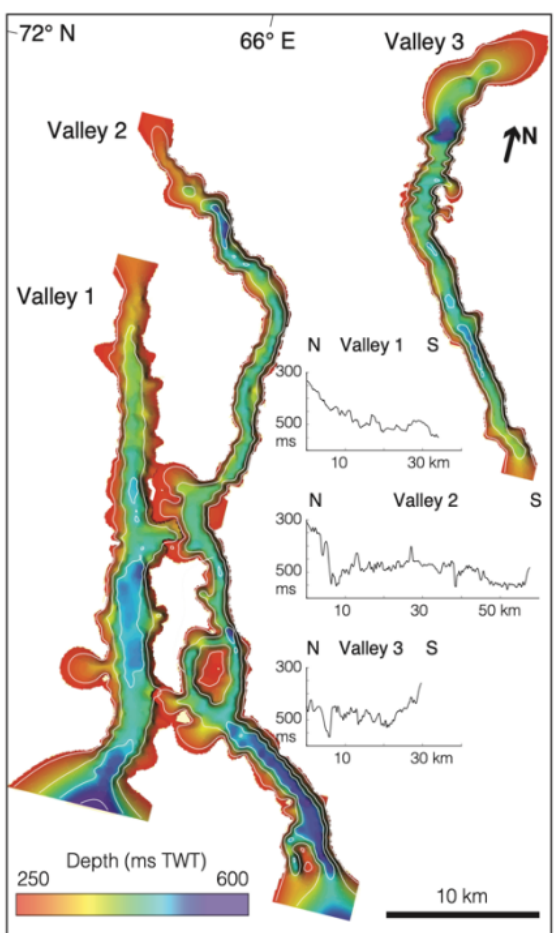

